\title{
Mollusks Found Inside Octopus (Mollusca, Cephalopoda) Pots in the State of Ceará, Northeast Brazil
}

\author{
Helena Matthews-Cascon ${ }^{*}, 1,2$, Cristina Rocha-Barreira ${ }^{2}$, Reynaldo Amorim Marinho², \\ Lorena Galletti de Almeida ${ }^{3}$, Carlos Augusto Oliveira de Meirelles ${ }^{1,4}$ \\ ${ }^{I}$ Laboratório de Invertebrados Marinhos - LIMCE, Universidade Federal do Ceará, Centro de Ciências, Departamento \\ de Biologia, bloco 909 Campus do Pici. CEP. 60455-970, Fortaleza, Ceará, Brazil \\ ${ }^{2}$ Instituto de Ciências do Mar (Labomar) Universidade Federal do Ceará, Brazil \\ ${ }^{3}$ Mestrando em Ciências Marinhas Tropicais (Labomar) Universidade Federal do Ceará, Brazil \\ ${ }^{4}$ Doutorado em Engenharia de Pesca (Departamento de Eng. De Pesca) Universidade Federal do Ceará, Brazil
}

\begin{abstract}
The fishery of octopus in the State of Ceará is being carried out in the coast of Fortaleza, Redonda Beach (Icapuí) and Itarema where 2 species can be found, Octopus insularis and O. vulgaris. The objective of this study was to investigate which prey species of mollusks were found inside the pots used in the octopus fishery. Unbaited octopus pots were set in Redonda Beach at 30 meters depth, in Fortaleza at 27 meters depth, and in Itarema at 30 meters depth. The species found inside the octopus pots that were consumed by Octopus vulgaris and O. insularis were mainly gastropods and bivalves. It was found 32 species of mollusks, being 17 of gastropods and 15 of bivalves. Redonda Beach presented the higher number of mollusk species in the octopus pots, with $85 \%$ of the total. The most preyed gastropod species was Aliger costatus (35.6\%) and the most preyed bivalve species was Anadara notabilis (54.5\%). Among the gastropods, 54\% had a bore hole, the majority on the spire in the ventral side of the shell. This location is probably due to the presence of the columelar muscle, where it can inject the poison. Only $4.3 \%$ of the bivalves found inside the octopus pots presented bore holes. Empty shells were censured in the field to indicate the magnitude of octopus predation relative to other sources of mortality and the percentage of empty shells with octopus drill holes ranged from $14 \%$ to $69 \%$.
\end{abstract}

\section{INTRODUCTION}

The fishery of octopus in the State of Ceará, Northeast Brazil, is being carried out in the coast of Fortaleza, Redonda Beach (Icapuí) and Itarema (Fig. 1) where 2 species can be found, Octopus insularis and O. vulgaris. Octopus insularis has a patchy distribution restricted to hard substrates, with almost no occurrence in soft substrates, differently from $O$. vulgaris that can occur both in hard and soft substrates [1]. Octopus insularis (Fig. 2) is a medium-sized species with short and stout arms, deep web, large calamus and a rough reddish brown skin in preserved specimens [2]. Octopus vulgaris (Fig. 3) has large, ovoid wide mantle, long arms, rugose skin and small and inconspicuous ligula [3].

Octopus insularis and O. vulgaris have the same behavior when looking for food, the so called stop-go pattern [1, 4]. According to Villanueva [5] and Boyle and Rodhouse [6] $O$. vulgaris arms increase in length in relation to the rest of the body, which probably is an adaptation for feeding on larger organisms in the benthic community. On the other hand, $O$. insularis has small and strong arms and deep web that can be used to get small prey hidden in hard substrates and allow this species to catch more than one prey simultaneously [1].

*Address correspondence to this author at the Departamento de Biologia, Centro de Ciências, Universidade Federal do Ceará (UFC), Bloco 906 Campus do Pici 60455-760 Fortaleza, Ceará, Brazil; Tel: (85) 33669811, 33669813; Fax: (85) 33669806;

E-mail: hmc@ufc.br, helenamc@gmail.com
Octopus foraging behavior varied with local environmental conditions, but usually showed long pauses and short distance moves. The attack of an Octopus is a pounce during which many of the arms and the web are thrown over the prey to immobilize it and a bite and poisoning from the salivary glands are usual in many species [7].

Octopuses usually kill their shelled prey by drilling a small hole in the shell to inject poison [8]. A bore hole is formed through the shell of the prey with morphology typical of the type of shell. According to Runham et al. [9], holes drilled by Eledone cirrhosa in gastropod preys is located in a small area near the top of the shell, while in the crab nearly $60 \%$ were located in the carapace with $80 \%$ of these occuring in the lower left quadrant. Holes drilled by Octopus have a characteristic shape and can easily be distinguished from the holes drilled by predatory gastropods as Naticidae and Muricidae.

The shallow water octopods create midden heaps near their dens that depict their food selection and the results of their feeding. Among these heaps frequently are found bored shells of other mollusks [10]. The radula probably selects sites to wear a hole through the shell where the octopus can inject the poison and later extract the soft body of the prey $[11,12]$.

The species of the genus Octopus generally inhabit rocky environments or environments with calcareous algae where it can find shelter areas. Because of this hiding behavior, the 


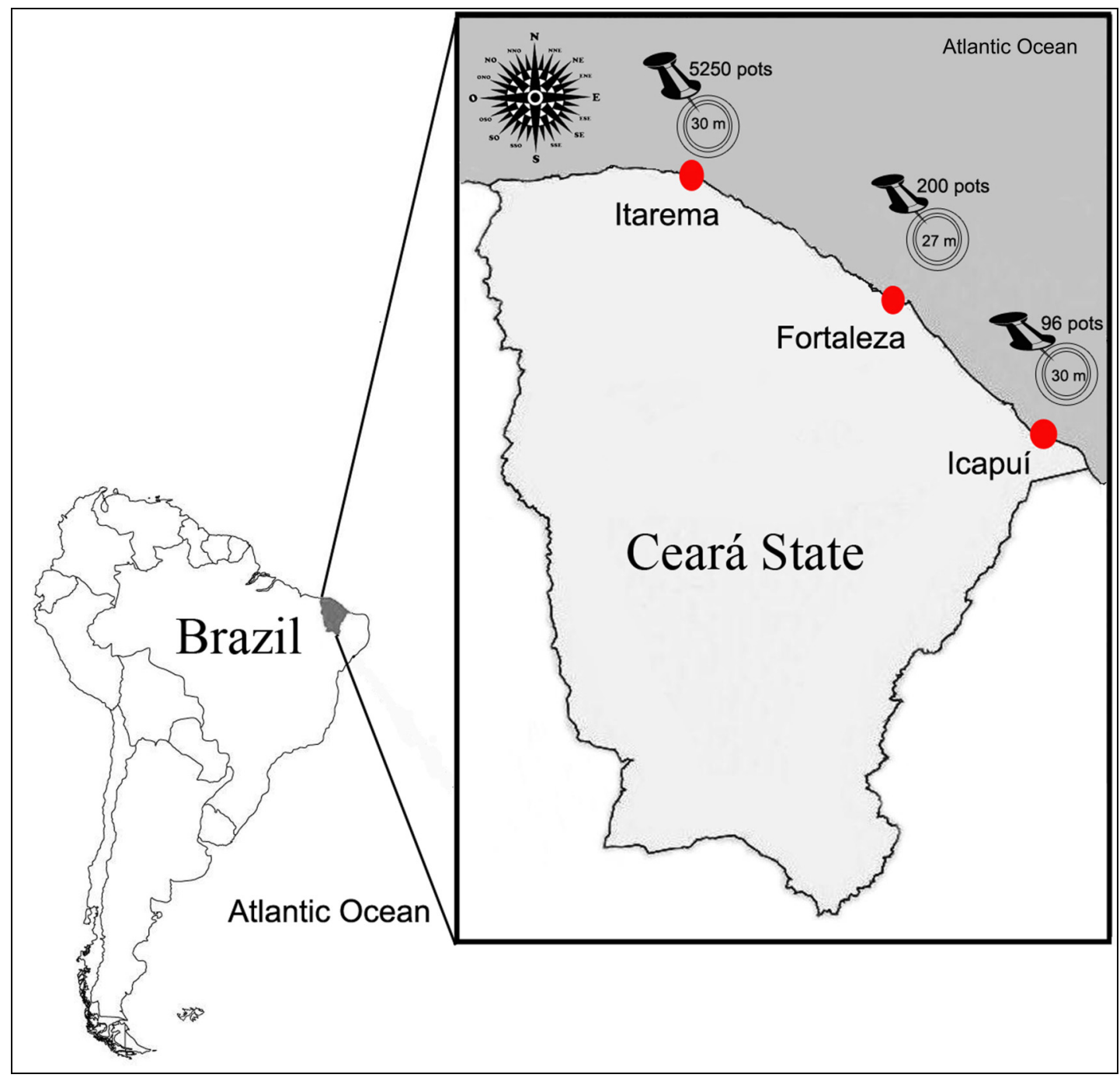

Fig. (1). Octopus fishery places in the State of Ceará, Northeast Brazil. The map shows that 96 octopus pots were set in Redonda Beach (Icapuí) at 30 meters depth, 200 octopus pots were set in Fortaleza at 27 meters depth and 5250 pots were set in Itarema at 30 meters depth.

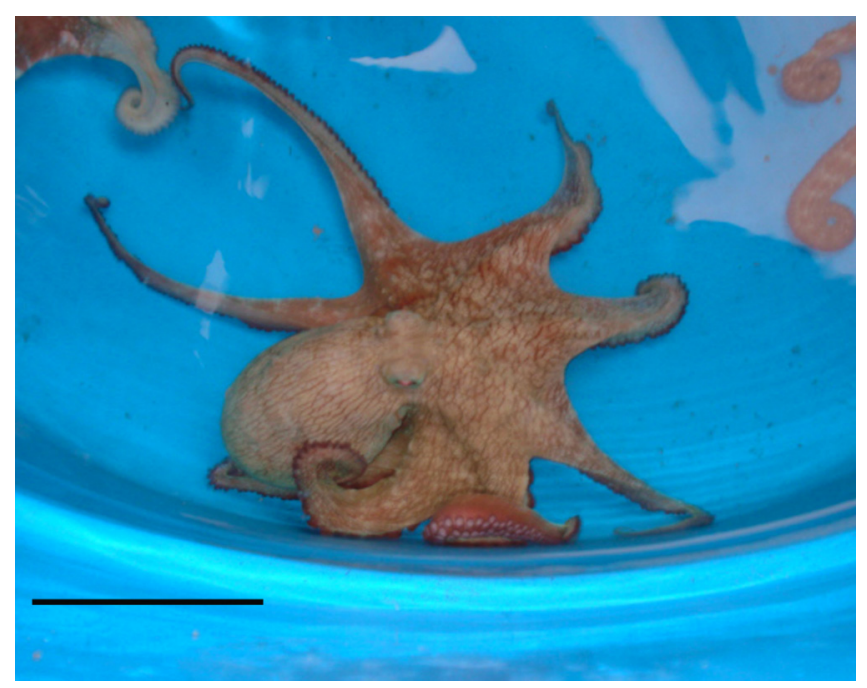

Fig. (2). Octopus insularis living specimen catch in octopus pots in Fortaleza, Ceará (scale bar: $7 \mathrm{~cm}$ ).

capture of these animals is generally carried out with traps as pots or tires where the animals enter searching for shelter. Octopus vulgaris is one of the most common octopus species commercially fished using unbaited pots [13] (Fig. 4). The pots draw the unsuspecting octopuses as a seemingly safe place and inside these shelters (pots) the octopus generally places its prey that can be other mollusks.

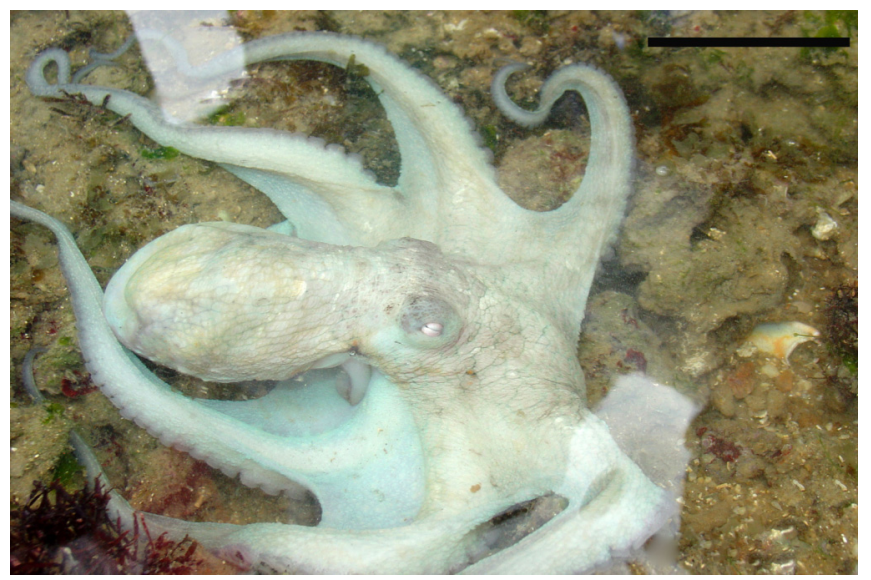

Fig. (3). Octopus vulgaris living specimen catch in octopus pots (scale bar: $7 \mathrm{~cm}$ ). 


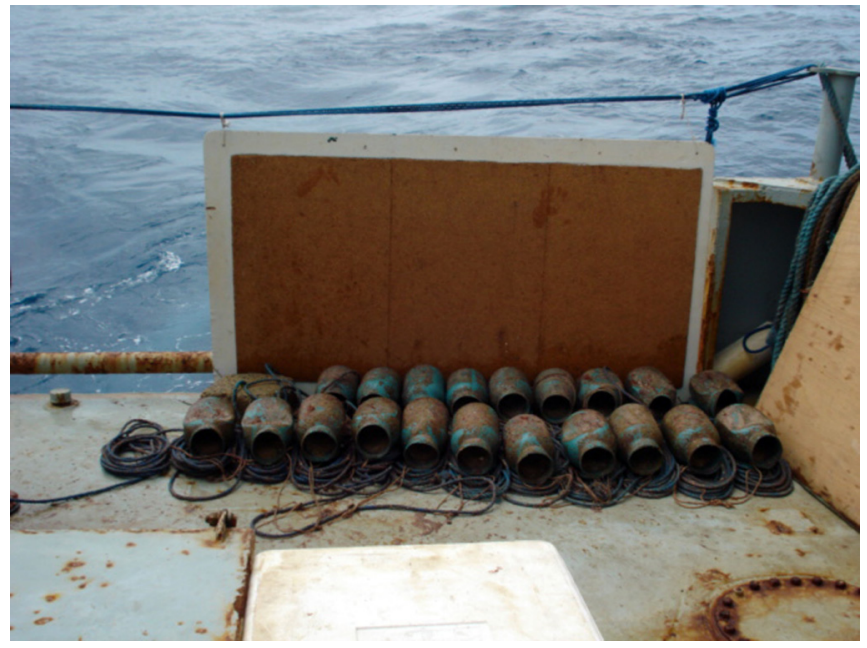

Fig. (4). Octopus pots that is used for fishery in Ceará state, Northeast Brazil.

The objective of this study is to investigate which prey species of mollusks can be found inside the octopus pots in the coast of Fortaleza, Redonda Beach (Icapuí) and Itarema, State of Ceará, Northeast Brazil.

\section{MATERIALS AND METHODOLOGY}

The traps, unbaited octopus pots (Figs. 4, 5) were set in Redonda Beach (Icapuí), Itarema and Fortaleza in the coast of the State of Ceará (Fig. 1). In Redonda Beach $\left(04^{\circ}\right.$ $18.260^{\prime} \mathrm{S}, 037^{\circ} 23.86^{\prime} \mathrm{W}$ ) it was set 96 octopus pots at 30 meters depth in December 2007 and April and May of 2008. In Fortaleza $\left(03^{\circ} 36.236^{\prime} \mathrm{S}, 038^{\circ} 19.108^{\prime} \mathrm{W}\right)$ it was set 200 octopus pots at 27 meters depth in March and May of 2008. In Itarema $\left(02^{\circ} 24.84^{\prime} \mathrm{S}, 039^{\circ} 54.61^{\prime} \mathrm{W}\right)$ it was set 5250 octopus pots at 30 meters depth in November of 2007 (Fig. 1). Itarema site had more pots set than the other sites because it is an important fishery area of octopus in the State of Ceará and most of the production is for export markets. In the other 2 sites, Fortaleza and Icapuí, the production is only for local market.

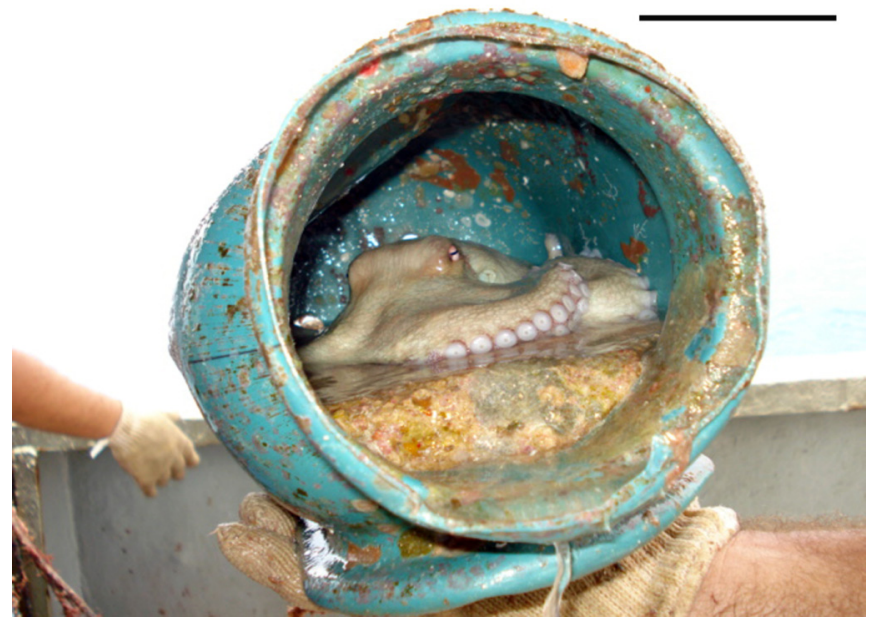

Fig. (5). Octopus pots with an Octopus insularis inside (scale bar: $15 \mathrm{~cm})$.

\section{RESULTS}

It was found 32 species of mollusks in the octopus pots, being 17 gastropods and 15 bivalves (Table 1). Redonda
Beach presented the higher number of mollusk species in the octopus pots, with $85 \%$ of the total (Fig. 6). Among the gastropods, $54 \%$ had a bore hole, the majority on the spire in the ventral side of the shell (Fig. 7). The most preyed gastropod species was Aliger costatus (35.6\%) and the most preyed bivalve species was Anadara notabilis (54.5\%). Only $4.3 \%$ of the bivalves found inside the octopus pots presented bore holes. The latter were close to the umbo and were found in only two bivalve species, Trachycardium magnum and Anadara notabilis.

Table 1. Mollusks Found Inside the Octopus pots in the State of Ceará, Northeast Brazil

\begin{tabular}{|c|c|c|c|}
\hline Species & Fortaleza & Itarema & Redonda \\
\hline Aliger costatus & $\mathrm{X}$ & $\mathrm{X}$ & $\mathrm{X}$ \\
\hline Voluta ebraea & $\mathrm{X}$ & $\mathrm{X}$ & $\mathrm{X}$ \\
\hline Anadara notabilis & $\mathrm{X}$ & $\mathrm{X}$ & $\mathrm{X}$ \\
\hline Glycymeris decussata & & $\mathrm{X}$ & $\mathrm{X}$ \\
\hline Glycymeris undata & & $\mathrm{X}$ & $\mathrm{X}$ \\
\hline Modiolus americanus & $\mathrm{X}$ & & $\mathrm{X}$ \\
\hline Murex ротит & & & $\mathrm{X}$ \\
\hline Dosinia concentrica & & $\mathrm{X}$ & $\mathrm{X}$ \\
\hline Ventricolaria rigida & $\mathrm{X}$ & $\mathrm{X}$ & $\mathrm{X}$ \\
\hline Turbinella laevigata & $\mathrm{X}$ & & $\mathrm{X}$ \\
\hline Codakia orbicularis & $\mathrm{X}$ & $\mathrm{X}$ & \\
\hline Callista maculata & $\mathrm{X}$ & & \\
\hline Trachycardium magnum & $\mathrm{X}$ & $\mathrm{X}$ & $\mathrm{X}$ \\
\hline Strombus gallus & & $\mathrm{X}$ & $\mathrm{X}$ \\
\hline Erosaria acicularis & & $\mathrm{X}$ & \\
\hline Trigoniocardia media & & $\mathrm{X}$ & \\
\hline Turritella exoleta & & $\mathrm{X}$ & $\mathrm{X}$ \\
\hline Cymatium cynocephalum & & $\mathrm{X}$ & $\mathrm{X}$ \\
\hline Turbo canaliculatus & & & $\mathrm{X}$ \\
\hline Tellina petitiana & & & $\mathrm{X}$ \\
\hline Ancilla lienardi & & & $\mathrm{X}$ \\
\hline Oliva scripta & & & $\mathrm{X}$ \\
\hline Oliva circinata & & & $\mathrm{X}$ \\
\hline Pitar fulminata & & & $\mathrm{X}$ \\
\hline Natica marochiensis & & & $\mathrm{X}$ \\
\hline Astraea latispina & & & $\mathrm{X}$ \\
\hline Cymatium femorale & & & $\mathrm{X}$ \\
\hline Pleuroploca aurantiaca & & & $\mathrm{X}$ \\
\hline Pecten ziczac & $\mathrm{X}$ & & \\
\hline Miltha childrenae & & & $\mathrm{X}$ \\
\hline Spondylus americanus & & & $\mathrm{X}$ \\
\hline Tonna maculosa & & & $\mathrm{X}$ \\
\hline
\end{tabular}




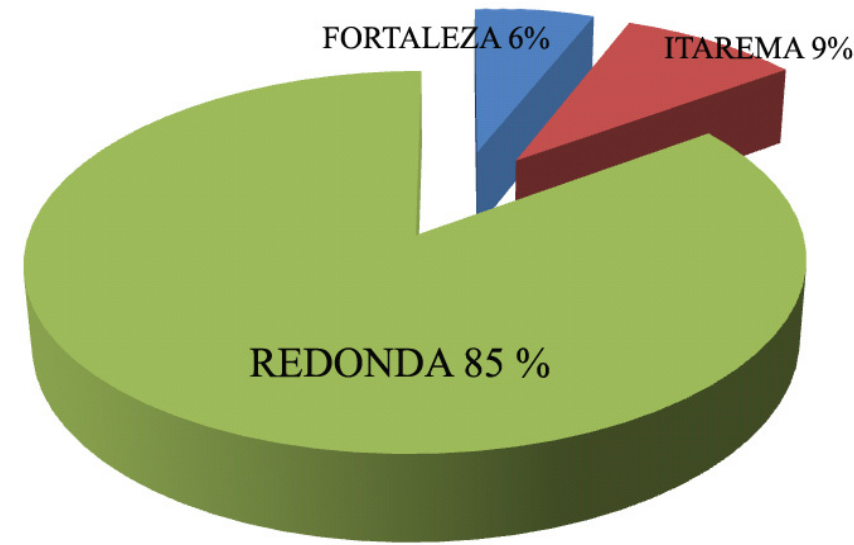

Fig. (6). Percentage of the mollusks species found in the area of the octopus fishery.

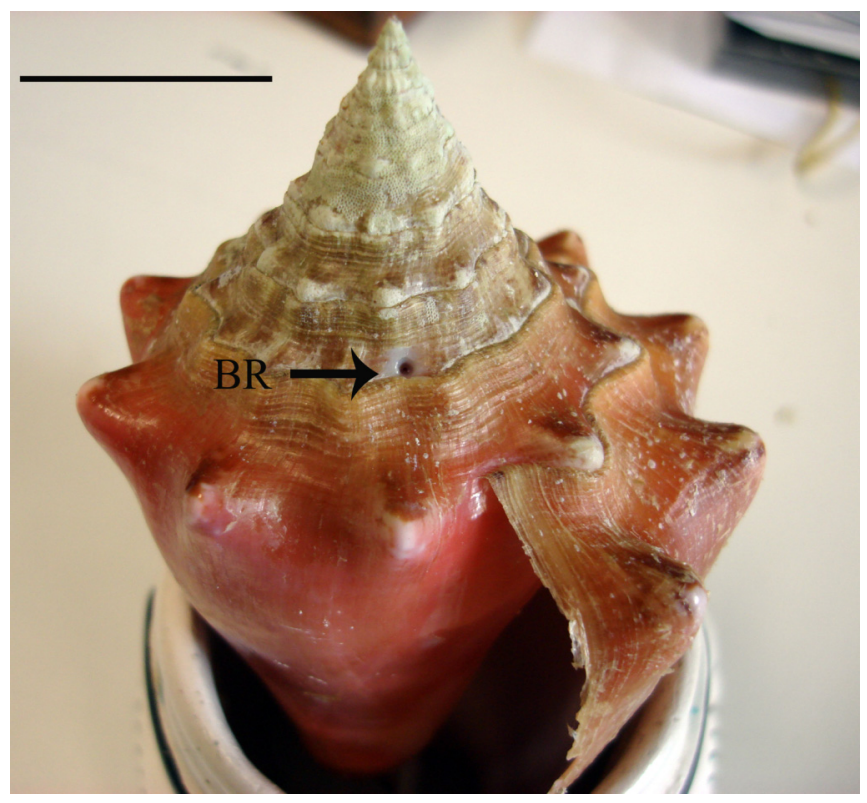

Fig. (7). Bore hole (BR) made by the octopus in Aliger costatus (scale bar: $5 \mathrm{~cm}$ ).

The species presented in octopus pots of the 3 locations were the gastropods Aliger costatus and Voluta ebraea, and the bivalves Anadara notabilis, Ventricolaria rigida and Trachycardium magnum. Inside the octopus pots were also found many rolled shells, some hermit crabs and calcareous algae (Halimeda sp., Rhodophyceae Melobesiae).

\section{DISCUSSION}

According to Leite [1] Octopus insularis is a generalist, preying in a large number of species. Others octopuses are also generalists as Octopus vulgaris and O. bimaculatus that consume a wide variety of motile benthic invertebrates [1416]. According to Smith [17] the dietary difference between study sites is indicative of the opportunistic nature of $O$. vulgaris with diet reflecting prey availability at the different sites.

According to Ambrose [15] octopuses are a major mortality source for their prey. Empty shells were censured in the field to indicate the magnitude of octopus predation relative to other sources of mortality and the percentage of empty shells with octopus drill holes ranged from $14 \%$ to
$69 \%$. Octopuses can drill holes on mollusks shells in 20-150 minutes [18].

In the present study, the species found inside the octopus pots that were consumed by Octopus vulgaris and $O$. insularis were mainly gastropods and bivalves. Leite [1] recorded that the most preyed species by $O$. insularis were crustaceans (Mithrax forceps, Pitho sp.). Among the mollusk species registered in the present study as preyed by octopus, only four (Trachycardium magnum, Ventricolaria rigida, Modiolus americanus and Tonna maculosa) were also previously registered as preyed by $O$. insularis [1], and this may be due to the opportunist eating behavior of these cephalopods, making their diet items related to the prey availability in their living area. According to Fiorito and Gherardi [19] mollusks are the preferred preys of Octopus vulgaris.

Aliger costatus inhabits sandy deposits in the calcareous algae substrate (Rhodophyceae, Lithothamnion) [20] whereas Voluta ebraea is an endemic volutid snail from North and Northeast Brazil [3, 21, 22]. Studies made by Matthews [23] recorded this species in depths below 15 meters, being more abundant in the zone between 25 to 40 meters, although some specimens could be found in shallow waters in the Ceará State [24]. Anadara notabilis inhabits sandy, grassy and gravel bottoms [3], whereas Ventricolaria rigida buries in soft bottoms in depth from 10 to $100 \mathrm{~m} \mathrm{[3]}$ and Trachycardium magnum inhabits sandy and calcareous algae bottoms at 20 to $150 \mathrm{~m} \mathrm{[3].}$

The position of the bore holes on the spire in the ventral side of the shell close to or over the site of attachment of the columelar muscle, probably is to make possible the injection of the poisoning from the salivary gland to relax the animal and then to pull the soft body from the aperture. Chemical etching of the shell is involved in the formation of the bore hole and there is an alternation of periods of rasping by the radula and chemical etching during the making of it [9]. According to Mather [18], O. vulgaris preying on crabs drill holes on the chelae of the crabs injecting paralyzing agents, proteolytic enzymes, and other substances from the saliva.

Octopus can use different modes of predation as opening of the shell, breaking the shell or drilling on the shell [25]. Aliger costatus was the species with the higher number of bore holes in the shell. This gastropod has a very hard shell and probably, drilling a hole was the better way to get on the flesh. When preying other items with a less hard shell it may be more advantageous to use other modes of predation as opening or breaking the shell.

Among the bivalves, Anadara notabilis was the most preyed species by the octopuses. It may be due to a higher abundance of this species in the field and to the fact that this bivalve does not have the sinus, and consequently it is not able to buried deep making them easier to catch. Enteroctopus dofleini presents 3 bivalve penetration techniques, shell drilling (using the radula), shell chipping and a shell drilling where the octopus uses it uses the chitinous beak. According to Anderson and Mather [26], such technique could allow the posterior salivary gland venom to weaken the adductor muscles holding the shells together is suggested by the preferred chip location on the anterior and posterior of the shells, close to these adductor muscles. 
Inside the octopus pots it was found many rolled shells, and calcareous algae (Halimeda sp. and Rhodophyceae). Octopus tetricus had the entrance of the shelter blocked by the addition of small boulders and debris, but only brooding females barricaded the shelter entrance. In the present study it was found rolled shells and calcareous alga in the octopus pots.

Though it was set more pots in Itarema than in the other sites, Redonda Beach presented the higher number of mollusk species $(85 \%)$. This variation could be due to differences in prey abundance between sites, but no information on this is available for the study areas. It was observed that the dorsal mantle length of the octopus Enteroctopus megalocyathus, in fishery zones at Chile, proved to be a better predictor of the variance in the diet composition $(16 \%)$ than the fishing zone $(6 \%)$. These low percentages are due to these octopuses forming a very homogeneous feeding group [27]

\section{ACKNOWLEDGEMENTS}

We would like to thank Dr. Paulo Cascon for help in discussion and criticism of the manuscript. We also thank Bruno Braulino Batista and Raul Malvino Madrid for the photography. The Marine Sciences Institute (Instituto de Ciências do Mar - LABOMAR) of the Federal University of Ceará (Universidade Federal do Ceará - UFC - Brazil) initiated the Project Northeast Octopus in June of 2007 with financing of the National Research and Tecnology Council (Conselho Nacional de Deselvonvimento Científico e Tecnológico - CNPq). This project has as objective to contribute for the improvement of the quality of life of the fishermen and for the sustainability of the local fisheries.

\section{REFERENCES}

[1] Leite TS. Taxonomia, distribuição, ecologia alimentar, pesca e opções de manejo de uma nova espécie de polvo (Octopus insularis: Cephalopoda), no Arquipélago de Fernando do Noronha, Brazil. Fundação Universidade Federal do Rio Grande PósGraduação em Oceanografia Biológica. 2007; Doutorado: 1-59.

[2] Leite TS, Haimovici M, Molina W, Warnke K. Morphological and genetic description of Octopus insularis, a new cryptic species in the Octopus vulgaris complex (Cephalopoda: Octopodidae) from the tropical Southwestern Atlantic. J Moll Stud 2008; 74: 63-74.

[3] Rios EC. Seashells of Brazil. In: Rio Grande, Ed. Fundação Universidade do Rio Grande 1994.

[4] Mather JA. Foraging, feeding and prey remains in midden of juveniles Octopus vulgaris (Mollusca: Cephalopoda). J Zool 1991; 224: 27-39.
[5] Villanueva R. Experimental rearing and growth of planktonic Octopus vulgaris from hatching to settlement. Can Bull Fish Aquat Sci 1995; 52: 2639-50.

[6] Boyle P, Rodhouse P. Cephalopods, Ecology and fisheries. Blakwell Science, Oxford 2005.

[7] Well MJ. Octopus, Physiology and Behavior of an Advanced Invertebrate. Chapman \& Hall, London 1978.

[8] Pilson MEQ, Taylor PB. Hole drilling by octopus. Science 1961; 134: $1366-8$

[9] Runham NW, Bailey CJ, Carr M, Evans CA, Malham S. Hole drilling in crab and gstropod shells by Eledone cirrhosa (Lamarck, 1798). Sci Mar 1997; 61 (Suppl 2): 67-76.

[10] Summers WC. In: Russell-Hunter WD, Ed. The Mollusca ecology, physiological and trophic ecology of cephalopods. New York: Academic Press 1983; Vol. 6: pp. 261-79.

[11] Arnold JM, Arnold KO. Some aspects of hole-boring predation by Octopus vulgaris. Am Zool 1969; 9: 991-6.

[12] Wodinski J. Penetration of the shell and feeding on gastropods by Octopus. Am Zool 1969; 9: 997-1010.

[13] Oosthuizen A. Economic feasibility of an experimental octopus fishery in South Africa. South Afr J Sci 2004; 100: 595-602.

[14] Mangold K. Food, feeding and growth in cephalopods. Meml Nat Mus Victoria 1983; 44: 81-93.

[15] Ambrose RF. Effects of octopus predation on motile invertebrates in a rocky subtidal community. Mar Ecol Prog Ser 1986; 30: 26173 .

[16] Jambeiro AF. Biologia quantitativa da população de Octopus vulgaris Cuvier, 1797 no ecossistema recifal de Guarapuá, Cairu - Bahia. Instituto de Biologia, Monografia de conclusão de curso Bacharelado 2002; pp. 110.

[17] Smith CD. Diet of Octopus vulgaris in False Bay, South Africa. Mar Biol 2003; 143:1127-33.

[18] Mather JA, Nixon M. Octopus vulgaris (Cephalopoda) drills the chelae of crabs in Bermuda. J Moll Stud 1995; 61: 405-6.

[19] Fiorito G, Gherardi F. Prey-handling behaviour of Octopus vulgaris (Mollusca, Cephalopoda) on bivalve preys. Behav Proc 1999; 46: 75-88.

[20] Matthews HR. Moluscos Brazileiros da familia strombidae (gastropoda, prosobranquia). Univ. Federal do Paraná 1976.

[21] Clench WJ, Turner RD. The subfamilies volutinae, zidoninae, odontocymbiolinae and calliotectinae in the western atlantic. Johnsonia 1964; 4: 129-80.

[22] Cosel RV. Contribución al conocimiento del género Voluta Linné, 1758 (Prosobranchia) en la costa del Caribe de Colombia. Mitt Inst Colombo-Alemán Invest Cient 1976; 8: 83-104.

[23] Matthews HR. Notas sobre a família Volutidae no Nordeste Brasileiro (Mollusca: Gastropoda). Arq Ciên Mar 1969; 9: 71-5.

[24] Cordeiro GV. Estudo sistemático e anatômico de Voluta ebraea Linnaeus, 1758 (Mollusca: Gastropoda: Volutidae). Universidade Federal do Ceará 1999.

[25] Hughes RN. Predation and community structure. The shore environment: Ecosystems. New York, Academic Press Vol. 2; .1980.

[26] Anderson RC, Mather JA. The packaging problem: bivalve prey selection and prey entry techniques of the octopus Enteroctopus dofleini. J Comp Psychol 2007; 121: 300-5.

[27] Ibáñez CM, Chong JV. Feeding ecology of Enteroctopus megalocyathus (Cephalopoda: Octopodidae) in southern Chile. J Mar Biol Assoc UK 2008; 88: 793-8. 